\title{
OS PRECEDENTES JUDICIAIS NO BRASIL E OS PRINCÍPIOS CONSTITUCIONAIS DA SEGURANÇA JURÍDICA, DA RAZOÁVEL DURAÇÃO DO PROCESSO E DA IGUALDADE
}

\author{
Karla Fernandez Gomes \\ Especialista em Direito Processual (FA7). Advogada. \\ Artigo sob a orientação do prof. Me. Felipe dos Reis Barroso \\ (FA7). \\ karlafernandezg@hotmail.com
}

SUMÁRIO: Introdução. 1. Os precedentes judiciais. 2. Os precedentes judiciais e os postulados da segurança jurídica, da igualdade e da razoável duração do processo. 3. Os precedentes judiciais no direito brasileiro. Considerações Finais. Referências.

Resumo: O presente artigo analisa os precedentes judiciais frente aos postulados constitucionais da segurança jurídica, da razoável duração do processo e da igualdade. Afere se no direito brasileiro dá-se ou não respeito a estes. Como resultado se evidenciou a necessidade da aplicação da doutrina do stare decisis no Brasil, a fim de que sejam assegurados os direitos fundamentais à segurança jurídica, à igualdade e à razoável duração do processo, e, por consequência, a própria eficácia da atividade jurisdicional..

Palavras-chave: Precedentes Judiciais. Direito Brasileiro. Segurança Jurídica. Igualdade. Razoável Duração do Processo..

\section{INTRODUÇÃo}

Ao observarmos a jurisprudência pátria, percebemos a ocorrência de decisões judiciais, sobretudo nos Tribunais Superiores, que passam a atribuir força vinculante à ratio decidendi, razão pela qual em outros casos que se apresentam símiles ao anteriormente julgado, os Tribunais invocam o precedente judicial, o que parece estranho no sistema jurídico do civil law, vez que o sistema dos precedentes judiciais é instituto decorrente do common law.

É cediço que a Constituição Federal de 1988, por meio da Emenda Constitucional $\mathrm{n}^{\circ} 45$, de 8 de dezembro de 2004, inseriu no rol dos direitos fundamentais o princípio da razoável duração do processo (art. $5^{\circ}$, inc. LXXVIII, da CRFB).

No entanto, no direito brasileiro, tem-se verificado, na prática, que o princípio da razoável duração do processo não tem se efetivado em muitos feitos, justamente porque o Judiciário se encontra abarrotado de demandas, muitas até concernentes a uma mesma questão jurídica, junto a outros fatores que também contribuem para demora na solução dos litígios, como o elevado número de recursos e ainda o costume da sociedade brasileira de recorrer ao Judiciário até em causas que efetivamente poderiam ser resolvidas por outros meios de solução do conflito. 
A Carta Magna consagra o princípio da igualdade como garantia fundamental (art. $5^{\circ}$, caput, da CRFB), bem como o princípio da segurança jurídica, que pode ser extraído da proteção à coisa julgada, ao ato jurídico perfeito e ao direito adquirido (art. $5^{\circ}$, inc. XXXVI, da CRFB).

Entretanto, constata-se que postulado da segurança jurídica também não vem sendo observado, pois, cotidianamente, são prolatadas decisões distintas em casos assemelhados, às vezes completamente destoantes, o que viola a segurança jurídica, bem como constitui mácula ao princípio da isonomia, já que se atesta tratamento desigual entre os jurisdicionados.

Desta feita, ante a constatação de que alguns Tribunais já vêm atribuindo força aos precedentes judiciais, do elevado número de demandas e do mandamus constitucional da razoável duração do processo, da isonomia e da segurança jurídica, urge esmiuçar o tema acerca da aplicação do sistema dos precedentes judiciais no direito pátrio, averiguando sua viabilidade e suas consequências.

Diante do exposto, no decorrer deste artigo, tenta-se responder aos seguintes questionamentos: é lícita a aplicação do sistema dos precedentes no direito brasileiro? Os precedentes judiciais se constituem como meios de efetivação dos princípios da segurança jurídica, da igualdade e da razoável duração do processo? Vem sendo atribuída força vinculante aos precedentes judiciais no direito brasileiro?

\section{Os Precedentes Judiciais}

No campo do direito comparado, dois sistemas jurídicos coexistem hoje: common law e o sistema romano-germânico, conhecido como civil law, dotados de características distintas em razão dos aspectos históricos e sociais que influenciaram a sua formação.

Não é difícil notar que a função dos precedentes judiciais nos ordenamentos filiados ao common law e da atividade jurisprudencial nos sistemas ligados ao civil law é relativamente distinta, até mesmo em virtude das próprias raízes e características centenárias de cada família do Direito. (LIMA, 2013, p. 114).

O sistema jurídico romano-germânico, ou civil law, pode ser compreendido como aquele que tem a lei como fonte principal do Direito, embora seu surgimento remonte à compilação e codificação do direito romano; galgou força na teoria da separação dos poderes, no advento do Positivismo e nos ideais da Revolução Francesa, a qual, em razão de consequências históricas, buscou limitar o poder dos juízes, atribuindo a eles a mera aplicação da lei.

\footnotetext{
[...]. Na teoria de Montesquieu, qualquer veleidade de dar-se aos juízes o poder de fazer a lei seria ir contra o postulado da separação dos poderes. Reforça-se, assim, a concepção piramidal do direito no sistema romano-germânico: o Judiciário é um poder que tem atributos dos mais amplos, não sendo controlado por nenhum dos outros dois, mas não tem iniciativa e seu poder é limitado pela res judicata; generalizações a partir de casos julgados só na matéria sub judice e sem qualquer possibilidade de criar precedentes, ou seja, de imporem-se a casos semelhantes no futuro, pela sua própria efetividade. (SOARES, 2000, p. 29).
}

Já no sistema jurídico common law, oriundo do direito britânico, nitidamente costumeiro, confere-se maior liberdade aos magistrados para dizerem o Direito, não os constituindo como meros aplicadores da lei, mas formadores deste, ao elencar os precedentes como sua fonte. Leciona Marinoni (2013, p 33): "Não há como negar a importância que o stare decisis teve para o desenvolvimento do common law em sua faceta hodierna, tampouco esquecer que os precedentes $-[\ldots]$ - constituem fonte de direito neste sistema". 
A ideia do direito inglês estava resguardada nos costumes e tradições, os quais, inclusive, iam se firmando com as decisões judiciais que o professavam, tudo porque, diferentemente da França, a Inglaterra passou pela Revolução Gloriosa (1688-1699), onde os magistrados foram preponderantes para limitar o poder do monarca absolutista. Nesse sentido, pronuncia-se Marinoni (2013, p. 33-34):

\begin{abstract}
Aliás, na tradição do common law inglês, o Parlamento considerava as decisões proferidas pelas Cortes nos casos concretos para, a partir delas, precisar e delinear a lei decorrente da vontade comum. Interessante perceber que exatamente aí surge uma primitiva noção de due process of law, visto como o caminho a ser seguido para a elaboração da lei ancorada nos costumes.

Neste sistema, o legislativo não se opôs ao judiciário, chegando, em realidade, a com ele se confundir. Na Inglaterra, o juiz esteve ao lado do Parlamento na luta contra o arbítrio do monarca, reivindicando a tutela dos direitos e liberdades do cidadão. Por isso mesmo, ao contrário do que ocorreu em face da Revolução Francesa, não houve clima para desconfiar do judiciário ou para supor que os juízes se posicionariam em favor do rei ou do absolutismo.
\end{abstract}

Assim, a real distinção entre os dois sistemas jurídicos encontra-se no papel dos magistrados e não na questão da fonte preponderante do direito como muitos pensam, até porque atualmente no common law a lei tem conquistado mais espaço, mas o sistema persiste face ao papel que os juízes possuem neste e a doutrina do stare decisis.

\footnotetext{
Nos dias que correm, a diferença entre o magistrado do common law e do civil law não está na elasticidade das suas elaborações ou interpretações, mas na importância que eles assumem em cada um dos sistemas, e, por consequência, no respeito que lhes é devotado. E não é equivocado dizer que um dos principais responsáveis pelo traço forte da figura do juiz do common law é justamente o sistema de precedentes. (MARINONI, 2013, p. 40-41).
}

No mesmo sentido, destaca Marcelo Augusto Biehl Ortolan (2012, p. 17-18):

\begin{abstract}
A Revolução Inglesa, conduzida pelos nobres proprietários do Parlamento contra o absolutismo, diversamente da Revolução Francesa, não considerava os juízes como uma ameaça, mas antes como um poder amigo do Parlamento na luta contra as arbitrariedades do soberano. Por essa razão que, no direito inglês, não houve a necessidade de se criar o dogma da prevalência da lei e da aplicação estrita da lei pelo magistrado (juiz boca da lei), garantindo-lhe espaço e poder para interpretar a lei. Assim, a ideia da supremacia do parlamento inglês não teve a intenção de submeter o juiz à lei, como produto Parlamento.
\end{abstract}

Ademais, o civil law também já passou por diversas modificações, até porque negar a interpretação das normas pelos magistrados consistiu uma mera utopia. O advento do Constitucionalismo configurou-se como o ápice do repensar do civil law, já que as leis passaram a ter que estar em conformidade com o texto constitucional, o que vincula, sem dúvida, o Legislativo, mas também se constitui como encargo do poder Judiciário, ampliando a sua função, ante a necessidade do exercício do controle de constitucionalidade. Leciona Marinoni (2013, p. 67): "[...] o juiz do civil law passou a exercer papel que, em um só tempo, é inconcebível diante dos princípios clássicos do civil law e tão criativo quanto o seu colega do common law. [...].”.

A verdade é que, atualmente, esses sistemas jurídicos se aproximam e se entrelaçam. Notadamente, no Direito Brasileiro, que, apesar de oriundo do civil law, importou vários institutos do common law, sobretudo dos Estados Unidos da América, como a supremacia constitucional e o controle difuso de constitucionalidade. 
É de se notar, contudo, que tais sistemas não se desenvolveram de forma estanque e que tampouco permanecem estagnados e incomunicáveis. Ao longo de sua formação, sofreram influências recíprocas e, hoje, se encontram em claro processo de aproximação. [...]. (MELLO, 2008, p. 13).

Neste cenário, questiona-se a doutrina do stare decisis, a qual enuncia a observância dos precedentes judiciais, se foi ou não absorvida pelo direito pátrio. Destaca Marinoni (2013, p. 22):

\begin{abstract}
Não obstante as transformações que se operaram no civil law - inclusive nas concepções de direito e de jurisdição, marcadamente em virtude do constitucionalismo - e as especificidades do sistema brasileiro - que se submete ao controle difuso da constitucionalidade da lei - há notória resistência, para não se dizer indiferença, à importância ao aperfeiçoamento do nosso direito, como é o caso do respeito aos precedentes.
\end{abstract}

Entretanto, antes de demonstrar as razões que apontam para o necessário respeito aos precedentes e a própria viabilidade da aplicação da doutrina do stare decisis no direito brasileiro, faz-se primordial a compreensão de que decisões se constituem como precedentes, bem como as características e implicações destes.

É salutar destacar que, embora os precedentes advenham das decisões judiciais, nem toda decisão judicial enseja na formação de um precedente, vez que este, na verdade, configura-se como a constatação de um direito ante a análise pelo poder Judiciário de caso específico que termine por trazer questão jurídica pendente de resolução. Assim, o precedente é expresso na ratio decidendi, vez que na decisão em que há formação deste, não é apenas solucionado o caso inter partes, mas também é resolvida questão jurídica, havendo assim nítida formação de direito. Daniel Mitidiero (2012, p. 134) assevera: "O precedente pode ser identificado como a ratio decidendi de um caso ou de uma questão jurídica - também conhecido como holding do caso. [...]”. E continua Mitidiero (2012, p. 134):

[...]. Os precedentes não são equivalentes às decisões judiciais. Eles são razões generalizáveis que podem ser identificadas a partir de decisões judiciais. O precedente é formado a partir da decisão judicial. E porque tem como matéria-prima a decisão, o precedente trabalha essencialmente sobre fatos jurídicos relevantes que compõem o caso examinado pela jurisdição e que determinaram a prolação da decisão da maneira como foi prolatada.

Neste diapasão, fala-se nos precedentes judicias como formadores do Direito, já que, por decidirem uma questão jurídica, terminam não só por resolver aquele caso em análise, mas declaram um direito diante de uma situação jurídica. É, exatamente, neste aspecto que os adeptos do civil law se contrapõem à doutrina dos precedentes, vez que afirmam que o poder Judiciário estaria legislando, existindo clara mácula ao princípio da separação dos poderes.

No entanto, constituiria uma utopia reservar ao poder Judiciário a atividade de dizer o Direito e, simultaneamente, negá-lo a aferição da solução para uma questão jurídica, a qual não se restringe à subsunção dos fatos à norma, nem mesmo a interpretação das disposições das leis, mas a interpretação do ordenamento jurídico como um todo, passando pela conformidade com a ordem constitucional. Leciona Marinoni (2013, p. 70): “A dificuldade em ver o papel do juiz sob o neoconstitucionalismo impede que se perceba que a tarefa do juiz do civil law, na atualidade, está muito próxima da exercida pelo juiz do common law. [..].

O que se verifica, hodiernamente, é que os sistemas jurídicos do civil law e common law, nas suas versões iniciais, não mais subsistem. Não há como se falar, atualmente, no Judiciário 
como mero aplicador da lei (juge bouche de la loi), tampouco pensar no direito ocidental contemporâneo sem uma Constituição ou numa completa ausência de normas escritas.

Com o advento do Constitucionalismo, estabeleceu-se a hierarquia da norma constitucional em contraponto com as demais normas. Assim, toda norma passa a ter que estar em consonância com o texto constitucional, tendo, inclusive, o ordenamento pátrio adotado um sistema de controle de constitucionalidade misto, importando o concentrado do direito austríaco (civil law) e o difuso do modelo norte-americano (common law), o que só reforça que o direito brasileiro, apesar de oriundo do sistema do civil law, possui nitidamente institutos decorrentes do common law.

Dessa forma, se o próprio sistema jurídico adotado no Brasil pode ser compreendido como híbrido, a justificativa para o não respeito aos precedentes por ser o direito brasileiro oriundo do civil law, quando estes se constituem como institutos do common law, não encontra qualquer guarida.

Na verdade, a insistência ao não respeito aos precedentes judiciais num sistema que adota o controle de constitucionalidade difuso pode vir a gerar consequências graves ao próprio sistema jurídico. É que a possibilidade de qualquer juiz realizar o controle de constitucionalidade da norma, embora no caso específico, pode vir a gerar decisões contraditórias quando comparadas demandas concernentes à mesma questão de direito, o que enseja uma insegurança jurídica, descrédito ao poder Judiciário e tratamento desigual aos jurisdicionados.

\begin{abstract}
Não é isso, contudo, o que ocorre em nosso país, onde a garantia de liberdade de convicção dos juízes associada ao seu poder de declarar a inconstitucionalidade de normas está em constante choque com a missão constitucionalmente entregue ao Supremo Tribunal Federal, que é dar a última palavra acerca do sentido constitucional das normas. As razões suscitadas para se furtar à observância das decisões de nosso Supremo Tribunal - mesmo daquelas tomadas em controle abstrato, que deveriam ter eficácia erga omnes e efeito vinculante, são das mais variadas. Da mesma forma, observe-se que apesar da Constituição ser clara a respeito da missão institucional do Superior Tribunal de Justiça, que é definir a interpretação do direito federal, dando-lhe uniformidade, o mesmo descaso recai sobre suas decisões, que não são respeitadas nem pelos tribunais e juízos estaduais, nem pelos federais. (ORTOLAN, 2012, p. 35-36).
\end{abstract}

Neste cenário, faz-se necessário uma análise dos precedentes frente aos postulados da igualdade, da segurança jurídica e da razoável duração do processo, a fim de concluir se a "fuga" à aplicação dos precedentes está ou não ensejando, no âmbito das decisões judiciais, um "clima" de instabilidade, insegurança jurídica, desigualdade e morosidade na solução dos conflitos.

\title{
2 Os Precedentes Judiciais e os Postulados da Segurança Jurídica, da Igualdade e da Razoável Duração do Processo
}

A Constituição Federal consagra os postulados da segurança jurídica (art. $5^{\circ}$, inc. XXXVI), da igualdade (art. $5^{\circ}$, caput) e da razoável duração do processo (art. $5^{\circ}$, inc. LXXVIII) como direitos fundamentais, os quais pelo próprio texto constitucional são autoaplicáveis $\left(\S 1^{\circ}\right.$ do $\operatorname{art.~} 5^{\circ}$ ), constituindo-se, inclusive, como cláusulas pétreas, conforme se depreende do art. 60 , $\S 4^{\circ}$, inc. IV, da Lei Maior.

Desta feita, quando o texto constitucional colaciona tais princípios como direitos fundamentais, busca atribuir proteção máxima a eles, bem com os consagra como valores concernentes ao Estado Democrático de Direito e à sociedade brasileira, o que torna inquestionável a necessidade de observância de tais princípios. 
O princípio da segurança jurídica constitui-se como postulado indispensável ao Estado de Direito. Não há como instituir uma ordem legal se ao mesmo tempo não se assegura a estabilidade desta. Leciona Marinoni (2012, p. 559): “A segurança jurídica, vista como estabilidade e continuidade da ordem jurídica e previsibilidade das consequências jurídicas de determinada conduta, é indispensável para a conformação de um Estado que pretenda ser 'Estado de Direito"'.

A segurança jurídica, inicialmente, esteve direcionada para atuação legislativa, no sentido de assegurar confiança, previsibilidade e estabilidade à legislação; contudo, com a superação do positivismo nas ciências jurídicas, a interpretação da norma veio assumir relevante e indispensável papel na expressão do Direito, sobretudo com a supremacia constitucional.

Nesse diapasão, o Judiciário tem dever de garantir a segurança jurídica, já que se constitui como o princípio inerente ao Estado de Direito. Entretanto, a jurisdição pode ou não conferir segurança às relações sociais, pois dependendo de como esta é exercida, pode ensejar instabilidade social e, por consequência, "balançar" a própria ordem jurídica.

Para se atestar, de fato, a segurança jurídica, fala-se em três condições a serem observadas: previsibilidade, estabilidade e confiança. Assim, no âmbito da atividade jurisdicional, as decisões judiciais devem possibilitar a efetivação desses valores.

\begin{abstract}
É claro que não se pretende que a interpretação dita autêntica, ou melhor, aquela realizada por meio das decisões judiciais, encontre sempre uma, e só uma, solução possível e absolutamente correta, mas segundo Dewey possam ser realizadas dentro de "uma lógica de previsão de possibilidade e não de dedução de certezas". É nesta medida que as decisões devem seguir um padrão estabelecido pelas normas - abstratas e concretas - na medida em que são previsivelmente determinadas, ou seja, capazes de estabelecer uma moldura mínima ao conteúdo material das decisões, bem como uma exata legitimidade da forma de sua produção - mas também porque devem ser aplicadas dentro de uma moldura de elementos argumentativos justificadores que levam a uma razoável previsibilidade dos usos da coerção estatal. (POLICHUK, 2012, p. 163).
\end{abstract}

A previsibilidade das decisões judiciais se consagra pela uniformidade da interpretação das normas pelo Judiciário, já que, na atividade jurisdicional, quando firma-se um entendimento acerca de uma questão jurídica se assegura a previsibilidade da jurisdição, possibilitando o real conhecimento do ordenamento jurídico pela sociedade.

\footnotetext{
Em outra perspectiva, a segurança jurídica reflete a necessidade de a ordem jurídica ser estável. Esta deve ter um mínimo de continuidade. E isso se aplica tanto à legislação quanto à produção judicial, embora ainda não haja, na prática dos tribunais brasileiros, qualquer preocupação com a estabilidade das decisões. Frise-se que a uniformidade na interpretação e aplicação do direito é um requisito indispensável ao Estado de Direito. Há de se perceber o quanto antes que há um grave problema num direito variável de acordo com o caso. (MARINONI, 2012, p. 561).
}

Dessa forma, atesta-se que o precedente judicial - formação da solução de uma questão jurídica - garante a previsibilidade da jurisdição, visto que permite que a sociedade conheça a ordem legal que a determina.

Da breve narrativa observamos que a necessidade de previsibilidade não é matéria nova, muito menos instituto criado de sobressalto com busca a remendar a imensa colcha de retalhos que sobrecarrega no regime legal. Ao contrário, a exigência de previsibilidade como elemento inerente ao princípio da segurança jurídica, portanto, 


\begin{abstract}
do próprio Estado Democrático de Direito é conceito antigo, todavia, por muitas vezes renegado e jogado às sombras pelos mais diversos argumentos.

Assim, surgem os questionamentos acerca da aproximação dos sistemas da Civil Law e da Commun Law, na medida em que a utilização dos precedentes (vinculantes) vastamente utilizados no sistema da Commun Law nos apontam uma solução, testada e aprovada, no sistema inglês e norte-americano, especialmente. (POLICHUK, 2012, p. 167).
\end{abstract}

Conforme Marinoni (2012, p. 566), a estabilidade das decisões judiciais também permeia como elemento necessário para garantir a segurança jurídica, pois não há como se falar em Estado de Direito sem assegurar a estabilidade da ordem jurídica, a qual não passa somente pela atividade legislativa, mas pelo exercício da jurisdição, que sendo ato de poder, deve também conferir estabilidade.

O citado autor (2012, p. 571-573) ainda explica que, para conferir segurança jurídica, se faz necessário também tutelar a confiança dos jurisdicionados, o que, sem dúvida, confere-se através da previsibilidade e estabilidade das decisões judiciais, as quais possibilitam a ciência e a certeza dos atos do Judiciário pela sociedade.

Assim, verifica-se que os precedentes judiciais, por garantirem a previsibilidade das decisões judiciais, geram a estabilidade nas relações sociais e a confiança da sociedade na atividade jurisdicional.

Portanto, não resta dúvida que os precedentes se constituem como meio pelo qual se efetiva o mandamus constitucional da segurança jurídica, pois promovem a previsibilidade e estabilidade da jurisdição, o que enseja a segurança das relações sociais e a credibilidade do Judiciário.

AConstituição Federal de 1988 elencou no rol dos direitos fundamentais o princípio da igualdade como valor a orientar a aplicação de todas as demais garantias fundamentais, conforme se depreende do caput do art. $5^{\circ}$ da Lei Maior, ficando claro que a isonomia figura-se como ordem dada pela CRFB.

\begin{abstract}
Não é preciso lembrar que a igualdade é elemento indissociável do Estado Democrático de Direito e, bem por isso, está fortemente grifado na Constituição Federal, iluminando a compreensão, aplicação e a construção do ordenamento jurídico. (MARINONI, 2012, p. 577).
\end{abstract}

No campo doutrinário, fala-se em isonomia material e formal, pois a ordem constitucional importa na isonomia de submissão às normas, mas também na promoção da igualdade da aplicação da norma em contraponto às situações jurídicas apresentadas, o que fundamenta o tratamento igual dos iguais e desigual dos desiguais na medida de suas desigualdades.

Neste contexto, lembra-se que o direito fundamental ao processo justo e célere perpassa pela cláusula geral da isonomia, bem como que o exercício da atividade jurisdicional, que tem por escopo garantir a observância ao ordenamento jurídico pátrio, está submetido ao princípio da igualdade, razão pela qual o Judiciário deve observá-lo.

\footnotetext{
Se há uma definição judicial de direito fundamental, ou mesmo acerca do significado de uma lei federal, todos devem ser tratados igualmente perante eles. A menos, é claro, que se admita que a jurisdição possa e deva conviver com vários significados de um mesmo direito fundamental ou de uma mesma lei federal, o que eliminaria qualquer possibilidade de se ter uma elaboração teórica racionalmente capaz de explicar a legitimidade de uma decisão que afirma direito fundamental e deixaria sem qualquer razão de ser as normas constitucionais que consagram as funções
} 
jurisdicionais de uniformização da interpretação da lei federal e de atribuição de sentido à Constituição, além de, obviamente, violar a ideia imprescindível de igualdade perante a jurisdição. (MARINONI, 2012, p. 583).

Logo, quando no exercício da jurisdição se olvida o respeito à isonomia entre os jurisdicionados, há ofensa à Constituição Federal e ao próprio Estado Democrático de Direito, pois este não se faz possível em uma ordem legal que não consagra a igualdade.

\begin{abstract}
A isonomia reclamada é, portanto, a do Direito judicado, ou seja, aquele que resulta da interpretação judicial. E o processo de interpretação judicial da norma legislada impõe não apenas o conhecimento, mas também o reconhecimento dos precedentes judiciais, exatamente para evitar que o resultado prático da demanda seja diverso de caso semelhante já decidido, algumas vezes até por um órgão hierarquicamente superior. (LIMA, 2013, p. 153).
\end{abstract}

Daí se consta que a formação e o respeito aos precedentes judiciais garantem a observância ao princípio da igualdade, tendo em vista que promovem a isonomia entre os jurisdicionados.

O princípio da razoável duração do processo, como anteriormente destacado, passou a constar expressamente no rol dos direitos fundamentais (art. $5^{\circ}$, inc. LXXVIII, da CRFB) com a EC 45/2004; porém, na verdade, tal princípio já figurava como postulado fundamental, pois é inerente ao princípio do devido processo legal (art. $5^{\circ}$, inc. LIV, da CRFB).

Assim, a celeridade nos provimentos jurisdicionais se consagra como direito fundamental, justamente porque, ao se garantir uma ordem jurídica, a expressão desta, dada pela função jurisdicional, deve ser eficaz, de forma a possibilitar a eficiência das próprias normas que intitula.

A jurisdição morosa não só deslegitima a instituição à qual compete, mas também a própria ordem jurídica, já que a demora no firmamento da solução dos casos gera um "clima" de instabilidade e insegurança na sociedade, o que se aproxima à inexistência de ordem legal.

Desse modo, os precedentes judiciais configuram-se como verdadeiros garantes do princípio da razoável duração do processo, uma vez que, como já explicado, o precedente nada mais é do que o firmamento da solução de uma determinada questão jurídica; portanto, quando novamente for apresentada em juízo, naturalmente deve o juiz invocar o precedente, resolvendo aquela demanda.

Em primeiro lugar, a prática de os juízes e órgãos colegiados adotarem anteriores posicionamentos consolidados pelos tribunais superiores é algo que tende a reduzir a quantidade de recursos dos jurisdicionados sucumbentes, já que, conhecendo a jurisprudência do tribunal ad quem, e tendo sido a decisão proferida nesses exatos termos, será desestimulada a recorrer, com possível antecipação do trânsito em julgado e da execução do decisum, com entrega da prestação jurisdicional à parte vencedora. (LIMA, 2013, p. 157).

Além do que, como o precedente judicial é a resposta a uma questão jurídica, a sociedade já passa a ter ciência de como o Judiciário compreende aquela questão, o que enseja a rápida solução das lides e, muitas vezes, até previne o surgimento de novas demandas.

\footnotetext{
Ademais, a consolidação de entendimentos jurisprudenciais nas instâncias superiores seguida da sua reiteração pelos demais órgãos judiciários, indiretamente, desestimulará o ajuizamento de novas demandas por aqueles que confiavam na jurisprudência lotérica. Com a redução de novas ações sobre o mesmo tema, haverá uma desobstrução
} 
dos canais de acesso à justiça, permitindo que as demais causas sejam examinadas com mais vagar e num tempo mais curto. (LIMA, 2013, p. 158).

Logo, a adoção dos precedentes judiciais constitui meio pelo qual se assegura efetividade ao postulado constitucional da razoável duração do processo, pois, de fato, os precedentes geram um encurtamento do tempo de conclusão das lides e previnem o surgimento de novas demandas.

Contudo, constantemente, no exercício da função jurisdicional, os preceitos constitucionais da segurança jurídica, da razoável duração do processo e da igualdade vêm sendo violados, pois se atesta que são prolatadas decisões, em casos símiles, totalmente divergentes em juízos diversos e até no mesmo juízo, gerando um grau de instabilidade e de ausência de previsibilidade, que certamente afronta a segurança jurídica, bem como a igualdade entre os jurisdicionados, já que para uma mesma questão jurídica há várias respostas.

[...]. Sendo assim, é evidente que a jurisdição não encontra legitimação ao oferecer
decisões diversas para casos iguais ou ao gerar decisão distinta da que foi formada
no tribunal competente para a definição do sentindo e do significado das normas
constitucionais e dos direitos fundamentais. Na verdade, é pouco mais do que
absurdo pensar que o Poder Judiciário, caracterizado por um deficit de legitimidade
democrática em relação ao Legislativo, possa ter várias concepções acerca de
um mesmo direito fundamental, para num momento admitir e em outro negar a
constitucionalidade do produto da Casa habitada pelos representantes eleitos pela
maioria. (MARINONI, 2012, p. 583).

Ademais, o princípio da razoável duração do processo não tem se efetivado em muitos feitos, justamente porque, apesar de o Judiciário encontrar-se abarrotado de demandas, muitas referentes à mesma questão jurídica, não prima pela técnica dos precedentes, sendo, constantemente, prolatadas decisões completamente destoantes, o que fomenta a demora da resolução da lide. Frise-se que, muitas vezes, a parte para ver seu direito assegurado que por jurisprudência de Corte Superior se afigura possível, vê-se obrigada a recorrer até chegar ao juízo prolator do entendimento que está em consonância ao seu pleito.

[...]. O advogado do common law tem possibilidade de aconselhar o jurisdicionado porque pode se valer dos precedentes, ao contrário daquele que atua no civil law, que é obrigado a advertir o seu cliente que determinada lei pode - conforme o juiz sorteado para analisar o caso - ser interpretada em seu favor ou não. A lógica desta tradição não é apenas inversa, e assim faz surgir a nítida impressão de que o direito do civil law não é tão certo quanto o direito do common law, como milita e se volta contra o próprio sistema, na medida em que estimula a propositura de ações, o aumento da litigiosidade, o acúmulo de trabalho e o aprofundamento da lentidão do Poder Judiciário. (MARINONI, 2012, p. 562).

Neste diapasão, os precedentes se constituem como verdadeiros garantidores dos postulados constitucionais da segurança jurídica, da razoável duração do processo e da isonomia entre os jurisdicionados, posto que sinalizam como o poder Judiciário compreende certa questão jurídica, professando a solução cabível.

Dessa forma, sendo aplicado aos casos assemelhados, garante a segurança jurídica, a celeridade e a igualdade entre os jurisdicionados, o que se traduz como a expressão da própria justiça, pois como se falar nesta, ante a proliferação de decisões distintas frente à mesma situação jurídica? Marinoni (2013, p. 77) bem destaca: “[...]. O que justifica o respeito aos precedentes é a igualdade, a segurança jurídica e a previsibilidade.”. 
Quanto ao argumento contrário à doutrina do stare decisis que destaca que o direito é dinâmico, não podendo ser "engessado", primeiramente, pela Sociologia e Filosofia, relembra-se que o Direito surge como meio pelo qual se tenta conceder paz e justiça social, o que fica inviável num ambiente de diversas e contraditórias decisões judiciais. Na verdade, o próprio poder Judiciário perde sua legitimidade social, existindo apenas formalmente, em razão da perda da "fé" da sociedade nessa instituição.

Ademais, há técnicas que resolvem os possíveis problemas que surgiriam como aplicação do stare decisis, que, inclusive, já são empregadas no solo americano como, dentre outras, a revogação do precedente e o distinguished.

Os precedentes judiciais não "engessam" o Direito, pois quando o precedente se apresenta desconforme com a evolução social e do Direito, ele poderá ser superado através da sua revogação.

\begin{abstract}
Em outras palavras: a ausência de precedente com força obrigatória torna impossível a coerência das decisões judiciais - e, assim, do direito -, mas a evolução da doutrina pode demonstrar que o precedente, cuja força dava coerência ao sistema e ao direito, deve ser revogado para permitir a constituição de uma coerência capaz de espelhar o novo ou, em outros termos, um horizonte redefinido. De modo que respeitar precedentes não significa absolutizar a estabilidade e a certeza da jurisprudência. (MARINONI, 2013, p. 193).
\end{abstract}

Além do mais, segundo Marinoni (2013, p. 63-64), quando num caso específico verificam-se razões especiais para a não aplicação do precedente judicial, o juiz deverá proceder o distinguished, assegurando a isonomia material, que nada mais é do que a não aplicação do precedente em razão das peculiaridades do caso em tela. Para tanto, o magistrado deve fundamentar a sua decisão demonstrando por qual motivo o precedente não figura como a solução adequada.

Os princípios do livre convencimento motivado, do juiz natural e da independência dos magistrados são argumentos também levantados em contraponto à doutrina do stare decisis. Contudo, estes não vigoram, já que o poder Judiciário é uma instituição, logo, necessariamente, deve existir consenso no exercício de sua função. Bem destaca Marinoni (2012, p 566): "Não há como ter estabilidade quando os juízes e tribunais ordinários não se veem como peças de um sistema, mas se enxergam como dotados de autonomia para decidir o que bem quiserem".

\begin{abstract}
Ora, um organismo que tem manifestações contraditórias é, indubitavelmente, um organismo doente. Portanto, é preciso não confundir independência dos juízes com ausência de unidade, sob pena de, ao invés de se ter um sistema que racional e isonomicamente distribui justiça, ter-se algo que, mais do que falhar aos fins a que se destina, beira a um manicômio, onde vozes irremediavelmente contrastantes, de forma ilógica e improducente, se digladiam. (MARINONI, 2013, p. 203-204).
\end{abstract}

Portanto, o respeito aos precedentes compulsa como meio de efetivação dos princípios da segurança jurídica, da igualdade e, ainda, da razoável duração do processo, ou seja, como garantia de tais direitos fundamentais. Ademais, não há qualquer óbice à aplicação da doutrina do stare decisis, vez que devidamente aplicada não importa na ofensa a isonomia material ou no "engessamento" do direito, mas, pelo contrário, constitui meio pelo qual o poder Judiciário, eficazmente, pode cumprir sua função de distribuir paz e justiça social, pois esses valores são inalcançáveis num ambiente em que não se assegura igualdade, segurança jurídica e previsibilidade nas decisões judiciais. 


\title{
3 Os Precedentes Judiciais no Direito Brasileiro
}

Constata-se que o direito brasileiro adota um sistema híbrido, já que, apesar de oriundo do sistema romano-germânico, importou aspectos do common law, como a supremacia constitucional e a possibilidade do exercício do controle difuso de constitucionalidade. Contudo, não prima pela observância da doutrina da força vinculante dos precedentes judiciais (stare decisis), o que tem semeado a insegurança jurídica, tratamento desigual dos jurisdicionados, a demora na solução das lides e, ainda, a perda da legitimidade social do Poder Judiciário.

No Judiciário brasileiro, ainda é muito forte a ideia do livre convencimento motivado do juiz, porém, de forma distorcida, vez que se observa, constantemente, os magistrados dando soluções às lides conforme suas convicções e, tão somente, após a formação destas, buscam motivação para elas no ordenamento jurídico vigente, e, ainda, sem mesmo pesquisar como a matéria submetida a sua apreciação vem sendo enfrentada no próprio juízo ou mesmo nos Tribunais de segunda e última instâncias - o que se configura como ofensa à segurança jurídica, à igualdade e à razoável duração do processo, e, por consequência, à própria função jurisdicional.

\begin{abstract}
No direito brasileiro contemporâneo há uma absurda e curiosa não percepção da contradição existente entre a mitigação do duplo grau e a ausência de respeito às decisões dos tribunais superiores. De forma acrítica, ao mesmo tempo em que se vê na obrigatoriedade dos precedentes um atentado contra a liberdade do juiz, celebra-se o duplo grau de jurisdição como garantia de justiça. Os juízes pensam que exercem poder quando julgam como desejam, mas não percebem que não têm poder para decidir (sozinhos) sequer uma ação de despejo fundada em falta de pagamento ou uma ação ressarcitória derivada de acidente de trânsito, e, além disto, que as suas sentenças, em regra, não interferem na vida dos litigantes. (MARINONI, 2012, p. 568-569).
\end{abstract}

Ademais, frise-se, a situação se torna mais preocupante no contexto do direito brasileiro, vez que a possibilidade de qualquer juiz pugnar pela inconstitucionalidade de uma norma no caso concreto e de aplicar técnicas de interpretação conforme o texto constitucional, sem atentar para o respeito aos precedentes, não só enseja um "clima" de instabilidade, insegurança jurídica, desigualdade e morosidade na solução dos conflitos, mas também atenta contra o próprio texto constitucional que assegura ao Supremo Tribunal Federal a guarda e interpretação da Constituição.

No que respeita aos seus aspectos finalísticos, a adoção dos precedentes se justifica
na medida em que se busca promover alguns valores que lhe são correlatos, a saber:
a segurança e a previsibilidade jurídica; e uniformidade do direito e a isonomia
entre os cidadãos; a credibilidade das cortes; a redução de litígios, e a preservação
da força normativa da Constituição, em virtude do respeito à autoridade da exegese
produzida pelo STF. (PEREIRA, 2012, p. 152).

Comumente, verificam-se também decisões contrárias ao entendimento do Superior Tribunal de Justiça emanadas dos juízes e tribunais a quo, e o que é pior entre as próprias turmas do citado Tribunal Superior, quando é cediço que a Lei Maior salvaguardou a interpretação da lei federal a este.

Desse modo, ao observar atentamente a atividade jurisdicional brasileira atesta-se, em razão da não observância da doutrina do stare decisis, a não efetividade desta, pois um ordenamento que não consegue definir questões jurídicas, sendo exaradas decisões, cotidianamente, destoantes para casos parecidos, na verdade, sequer consegue transmitir para os jurisdicionados a certeza e o conhecimento de seus direitos, perdendo a legitimidade para sua própria função, que é a distribuição da justiça e a pacificação social. 


\begin{abstract}
Interessante notar, ainda, que a previsibilidade é relacionada aos atos do Judiciário, isto é, às decisões, mas que esta previsibilidade garante a confiabilidade do cidadão nos seus próprios direitos. Um sistema incapaz de garantir a previsibilidade, assim, não permite que o cidadão tome consciência dos seus direitos, impedindo a concretização da cidadania. (MARINONI, 2012, p. 565)
\end{abstract}

Assim, no Direito brasileiro, faz-se imperioso o respeito aos precedentes. Nesse sentido, bem assevera Marinoni (2012, 572-573): "Mesmo os ordenamentos de civil law, especialmente aqueles que dão ênfase ao controle difuso de constitucionalidade, não podem dispensar o esquema dos precedentes vinculantes para garantir a segurança jurídica e dar tutela à confiança.”.

\title{
Conclusão
}

Pelo exposto, conclui-se que o respeito aos precedentes judiciais compulsa como meio de garantir a segurança jurídica, a igualdade entre os jurisdicionados, a razoável duração do processo, a credibilidade do poder Judiciário e, por consequência, a própria eficácia da função jurisdicional.

Assim, diante da realidade verificada no exercício da jurisdição no Brasil, em que, cotidianamente, são prolatadas decisões em casos semelhantes, muitas vezes, completamente destoantes, atesta-se a existência de diversas soluções para uma mesma questão jurídica e um descaso às decisões dos Tribunais Superiores.

Neste contexto, a necessidade da adoção efetiva do sistema dos precedentes torna-se imperiosa, vez que não há como se falar em distribuição de justiça num ambiente em que não se assegura igualdade, segurança jurídica, celeridade e previsibilidade nas decisões judiciais.

\section{REFERÊNCIAS}

BRASIL. Constituição (1988). Constituição da República Federativa do Brasil. Brasília, DF, Senado, 1988.

LIMA, Thiago Asfor Rocha. Precedentes judicias civis no Brasil. São Paulo: Saraiva, 2013.

MELLO, Patrícia Perrone Campos. Precedentes: o desenvolvimento judicial do direito no constitucionalismo contemporâneo. Rio de Janeiro: Renovar, 2008.

MARINONI, Luiz Guilherme. Precedentes obrigatórios. 3. ed. rev. atual. e ampliada. São Paulo: Revista dos Tribunais, 2013.

O precedente na dimensão da segurança jurídica. In: MARINONI, Luiz Guilherme (Org.). A força dos precedentes: estudos dos cursos de mestrado e doutorado em direito processual civil da UFPR. 2. ed. rev. ampl. e atual. Salvador: Juspodivm, 2012, p. 559-575.

. O precedente na dimensão da igualdade. In: MARINONI, Luiz Guilherme (Org.). A força dos precedentes: estudos dos cursos de mestrado e doutorado em direito processual civil da UFPR. 2. ed. rev. ampl. e atual. Salvador: Juspodivm, 2012, p. 577-597. 
MITIDIERO, Daniel. Fundamentação e precedente - Dois discursos a partir da decisão judicial. In: MARINONI, Luiz Guilherme (Org.). A força dos precedentes: estudos dos cursos de mestrado e doutorado em direito processual civil da UFPR. 2. ed. rev. ampl. e atual. Salvador: Juspodivm, 2012, p. 125-142.

ORTOLAN. Marcelo Augusto Biehl. Commow law, judicial review e satare decisis: uma abordagem histórica do sistema de controle de constitucionalidade anglo-americano em perspectiva comparada como sistema brasileiro. In: MARINONI, Luiz Guilherme (Org.). A força dos precedentes: estudos dos cursos de mestrado e doutorado em direito processual civil da UFPR. 2. ed. rev. ampl. e atual. Salvador: Juspodivm, 2012, p. 15-40.

PEREIRA, Paula Pessoa. O Estado de direito e a necessidade de respeito aos precedentes judiciais. In: MARINONI, Luiz Guilherme (Org.). A força dos precedentes: estudos dos cursos de mestrado e doutorado em direito processual civil da UFPR. 2. ed. rev. ampl. e atual. Salvador: Juspodivm, 2012, p. 143-156.

POLICHUK, Renata. Precedente e segurança jurídica: a previsibilidade. In: MARINONI, Luiz Guilherme (Org.). A força dos precedentes: estudos dos cursos de mestrado e doutorado em direito processual civil da UFPR. 2. ed. rev. ampl. e atual. Salvador: Juspodivm, 2012, p. 157-170.

SOARES, Guido Fernando Silva. Common law: introdução ao direito dos EUA. 2. ed. São Paulo: Revista dos Tribunais, 2000.

\title{
JUDICIAL PRECEDENT IN BRAZIL AND CONSTITUTIONAL PRINCIPLES OF LEGAL CERTAINTY OF REASONABLE DURATION OF THE PROCESS AND EQUALITY
}

\begin{abstract}
This article analyzes the judicial precedents against constitutional postulates of legal certainty, the reasonable duration of the process and equality. The main objective of this work is to verify if the Brazilian Law respects such principles or not, according to the doctrine of stare decisis in Brazil
\end{abstract}

Keywords: Judicial precedents. Brazilian law. Legal certainty. Equality. Reasonable duration of the process.

Data de recebimento: out/2014 - Data de aprovação: dez/2014 
